\title{
RODANDO A BAIANA E INTERROGANDO UM PRINCÍPIO BÁSICO DO COMUNISMO E DA HISTÓRIA SOCIAL: \\ O Sentido Marxista Tradicional de Classe Operária*
}

\section{Interrogating a basic principle of Communism and Social History the traditional Marxist sense of working class}

"Fora-lhes dito que não tinham direitos, mas sabiam que nasceram livres"***

ResUmo: Procuro examinar nesse artigo os problemas do sentido marxista tradicional de classe operária para a História Social no Brasil. Ao fazer uma distinção entre o fenômeno histórico da classe trabalhadora inglesa das décadas de 1830 e 1840 e o modo como foi transformado em conceito, chamo atenção para especificidades históricas da formação da classe trabalhadora no Brasil. Estas especificidades têm de ser consideradas mas podem ser ignoradas se o uso dado ao conceito permanecer limitado ao sentido marxista tradicional de classe operária.

Palavras-Chave: Trabalhadores, classe social, classe trabalhadora, História Social, E. P. Thompson.

ABSTRACT: This article examines the problems of the traditional Marxist sense of working class for Social History in Brazil. In doing a distinction between the historical event of the English working class of the 1830's and 1840's and the ways it was converted into a concept, I address the historical peculiarities of the making of Brazilian working class. These ones must be considered but may be ignored if our appeal to the concept remains limited to the Marxist traditional sense of working class.

KEYWORDS: Workers, social class, working class, Social History, E. P. Thompson.

(recebido em $1^{\circ}$ de maio de 2012; aprovado em $1^{\circ}$ de junho de 2012)

\section{I}

Nascido primogênito numa família alemã em 1820, Engels foi criado nos rigores do calvinismo com o fito de herdar lucrativos negócios familiares. De fato, em 1842, embarcou (de primeira classe) em viagem para Manchester (Inglaterra), então um dos maiores sítios da indústria têxtil no mundo, para trabalhar na firma de seu pai, que andava inquieto com as peraltices do filho. No entanto, se o berço de ouro queria vê-lo proprietário afluente, Engels ficava cada vez mais intrigado pelo fenômeno dos despossuídos e dos excluídos: homens, mulheres e crianças que trabalhavam, por uma miséria, na novíssima invenção do planeta, a fábrica.

\footnotetext{
* Este artigo retoma e revê uma versão anterior, de igual título, publicada na coletânea Friedrich Engels e a ciência contemporânea, organizada por Mauro C. B. Moura, Muniz Ferreira e Ricardo Moreno, e publicada pela Edufba em 2007.

${ }^{* *}$ Professor de História da UFBa. Pesquisador CNPq e Fapesb. Pós-doutorado CPDOC/FGV.

*** THOMPSON, E. P. A formação da classe operária inglesa. Vol. III. Rio de Janeiro: Paz e Terra, 1987, p. 439.
} 
Depois de uma breve passagem pelo radicalismo alemão animado pelas rodas dos jovens hegelianos, Engels, já assumido como comunista, "acreditava estar a Inglaterra destinada à revolução social", o que o levou a escrever A situação da classe trabalhadora na Inglaterra, publicado em 1845. ${ }^{1}$ Os estudos e pesquisas bem como a publicação e os debates envolvidos nesse livro convenceram seu autor, mais do que já estava, de que a classe operária era uma criatura da Revolução Industrial e de que essa nova classe social não tardaria a ser 0 instrumento de instauração do comunismo. Para Engels, o proletariado viria a ser o coveiro da burguesia, a ser sepultada numa fossa que ela mesma teria aberto ao dar ao operariado (via Revolução Industrial). A depender de Engels, a burguesia era uma classe condenada, por suas próprias ações, a desaparecer nos escombros de uma poderosa vaga revolucionária.

Entre 1845 e 1850, Engels e Marx estreitaram relações e se tornaram amigos, parceiros e camaradas. O partido deles - ou a sua "tendência" - era o comunismo. Engels, ao mesmo tempo, rompia os últimos compromissos com seu pai, abandonava o papel de continuador (mas não o de herdeiro), e se dedicaria à militância, no continente europeu. Conservador, senhor de fé, fortuna e autoridade, o pai de Engels era um desses interlocutores invisíveis que os filhos carregam consigo, talvez para sempre. Não só isso, diga-se. Fora o componente freudiano, havia a ética protestante (sendo ambos bem alemães). Em 1839, o jovem Engels (anotou Leandro Konder) escrevera: "é fato que, entre os industriais, são os de religião puritana os que tratam pior os operários, diminuindo de todos os modos os salários deles, a pretexto de não lhes deixar dinheiro para se embriagarem".2

São daquele período animadas e estimulantes palestras e conversas, a intensa atividade agremiativa, panfletária e jornalística, assim como a preparação de dois escritos fundamentais, embora um seja menos conhecido do que o outro, mas não necessariamente menos bemsucedido na difusão de suas idéias. Trata-se dos Princípios básicos do comunismo, publicado apenas por Engels em 1847, e do Manifesto comunista, o poderoso livreto assinado por Engels e Marx no ano seguinte.

Falecido em 1895 (cerca de 13 anos depois de Marx), Engels era um destacado e proeminente curador do marxismo. Segundo Gareth Stedman Jones, ele foi, mais do que seu velho amigo, "responsável pela difusão do marxismo como visão do mundo, dentro do

\footnotetext{
1 STEDMAN JONES, Gareth. "Engels, Friedrich". BOTTOMORE, Tom (org.), Dicionário do pensamento marxista. Rio de Janeiro: Jorge Zahar Editor, 1988, p. 127. ENGELS, Friedrich, $A$ Situação da Classe Trabalhadora Inglesa. São Paulo: Global, 1986.

2 KONDER, Leandro. Marx. Vida e obra. Rio de Janeiro: José Álvaro Editor, 1968, p. 84.
} 
movimento socialista". ${ }^{3}$ Para tal, uma pequena - mas decisiva - contribuição sua se encontra no já citado Princípios básicos do comunismo, que aqui será abordado com o fito de interrogar o sentido marxista tradicional dado ao conceito de classe trabalhadora (ou operária). Além de ser uma das primeiras iniciativas de Engels com o intuito de esclarecer e instituir uma plataforma doutrinária e de ação dos comunistas no movimento operário europeu, os Princípios são, nas palavras de Hobsbawm, uma das duas versões preliminares do Manifesto Comunista. ${ }^{4}$

\title{
II
}

O que é esse sentido marxista tradicional? E qual sua relação com os Princípios básicos? O sentido marxista tradicional é um termo de E. P. Thompson para fazer referência a uma conjuntura histórica específica, o início da década de 1830, em que se insinua uma consciência de classe entre os trabalhadores da Inglaterra. Vale então dizer que, para Thompson, Engels viveu numa época em que os diversos grupos de trabalhadores se pautavam por uma "consciência de uma identidade de interesses" contraposta, numa relação, aos interesses de outras classes da sociedade inglesa. A partir de "sua experiência própria e com 0 recurso à sua instrução errante e arduamente obtida", esses trabalhadores ingleses da década de 1830:

\begin{abstract}
"formaram um quadro fundamentalmente político da organização da sociedade. Aprenderam a ver suas vidas como parte de uma história geral de conflitos entre, de um lado, o que se definia vagamente como 'classes industriosas' e, de outro, a Câmara não-reformada dos Comuns. De 1830 em diante, veio a amadurecer uma consciência de classe, no sentido marxista tradicional, mais claramente definida, com a qual os trabalhadores estavam cientes de prosseguir por conta própria em lutas antigas e novas". 5
\end{abstract}

Para Thompson, transpor a divisória entre os anos de 1832 e 1833 "é entrar num mundo onde a presença operária pode ser sentida em todos os condados da Inglaterra e na maioria dos âmbitos da vida". Nesse sentido, a classe operária "não está mais no seu fazer-se, mas já foi feita". Pintando com cores fortes a aparição dos trabalhadores como uma classe social, Thompson escreveu que o operariado havia então adquirido "uma ressonância singular na vida

\footnotetext{
${ }^{3}$ STEDMAN JONES. op. cit., p. 127.

${ }^{4}$ NEGRO, Antonio Luigi Negro. "Imperfeita ou refeita? O debate sobre o fazer-se da classe trabalhadora inglesa". Revista brasileira de história, vol. 16, o 31/32, 1996. Sobre a história do Manifesto, ver: HOBSBAWM, Eric. "Introdução ao Manifesto Comunista". Sobre história. São Paulo: Companhia das Letras, 1998, p. 321.

5 THOMPSON. A formação, op. cit., Vol. III, p. 304. Vol. II, p. 17. Para maiores detalhes, ver FORTES, Alexandre. "Miríades por toda a eternidade. A atualidade da Formação da classe operária inglesa". Tempo Social, vol.17, № 1, 2006.
} 
inglesa". "Tudo", arrematou, "converteu-se num campo de batalha de classe". Contudo, além de frisar que o fenômeno era novo (não possuía precedentes), sugeriu também sua especificidade: que talvez fosse uma "formação única essa classe operária inglesa de 1832". ${ }^{6}$

\section{III}

Então o que temos são dois olhares. Um é retrospectivo, o olhar de Thompson; outro, o de Engels, é contemporâneo. Embora ambos tenham se preocupado com o mesmo acontecimento (classe é um acontecimento, não é uma coisa dada), em Thompson, que olha a partir da segunda metade do século XX, o fenômeno histórico da classe trabalhadora inglesa madura em 1832 é congruente com o conceito de consciência de classe social (no seu uso marxista costumeiro). Há correspondência entre fenômeno e conceito. Já Engels, que chegou na Inglaterra em 1842, deu-se conta de que testemunhava um insólito fenômeno histórico, decisivo e particular. Assim, Engels parte do fenômeno histórico para a formulação do conceito de classe com consciência de classe. Antes de 1830, em lugar algum do planeta, era possível encontrar uma classe trabalhadora no sentido marxista tradicional, isto é, formada e madura, vale dizer, feita. Em 1831, Engels assinalou, "estala em Lyon [França] a primeira insurreição operária", mas foi entre 1838 e 1842, que chegou ao "auge o primeiro movimento operário nacional: o dos cartistas ingleses" ${ }^{7}$

Vale notar que Thompson escreveu $A$ formação da classe operária inglesa em desacordo com o autor de $A$ situação da classe trabalhadora na Inglaterra. $O$ historiador inglês rejeitou o que Engels afirmava: que a energia do motor a vapor somada à indústria algodoeira produziram a classe operária. Mesmo assim, o fato é que, para ambos, nos anos 1830, os trabalhadores ingleses se constituíram numa classe social, um acontecimento tanto empiricamente observável quanto peculiar. Apenas para frisar uma parte notável desse processo, em 1818 (ano em que Marx nasceu), um oficial fiandeiro de algodão teve sua palavra registrada num jornal. Manuseando essa fonte, Thompson demonstra a presença, na fala

\footnotetext{
6 THOMPSON. A formação, op. cit.. Vol. III, pp. 411, 438, 439. Vale notar que, noutra passagem (desta vez com ênfase maior), Thompson afirma ter sido a gentry do século XVIII inglês uma classe social "senão única, excepcional". Ver: idem, "As peculiaridades dos ingleses". As peculiaridades dos ingleses e outros artigos. Campinas: Editora da Unicamp, 2001, pp. 94 e 103.

7 ENGELS, Friedrich. Do socialismo utópico ao socialismo cientifico. São Paulo: Global, 1983, p. 52. Na visão de outros curadores do marxismo (afora Engels) - e citando Lênin -, o cartismo foi o "primeiro movimento operário amplo, verdadeiramente de massas, politicamente estruturado". Ver: Marx Engels. Obras Escolhidas, Tomo I. Lisboa: Edições Avante!, 1982, p. 566.
} 
operária, de elementos cruciais da economia política que Marx "dissecou" em o Capital... ${ }^{8}$ E tudo se passou em Manchester.

Porém, como observa Hobsbawm, há uma tensão entre a análise histórica do capitalismo e a filosofia da história do Manifesto Comunista (e dos Princípios básicos): "a tendência do desenvolvimento capitalista de gerar um proletariado essencialmente revolucionário não poderia ser deduzida da análise da natureza do desenvolvimento capitalista". Em outras palavras (e de novo citando Hobsbawm), entre servir de base para Engels e Marx conceberem 0 conceito de classe trabalhadora com uma "certa consciência de coletividade, de ser operário", isto é, entre "uma certa consciência de classe baseada na experiência muito específica de ser proletário" e esperar do operariado o abraço permanente a uma determinada forma de expressar-se com consciência de classe, há uma tensão verdadeira - impossível de aqui ser explorada mais a fundo, mas também impossível de ser esquecida. A manifestação madura do operariado inglês como uma classe serviu para despertar e catalisar, na dupla de amigos alemães, inquietações, expectativas e, também, uma teoria. De posse da observação do fenômeno, Engels e Marx passaram a escrever um papel para os trabalhadores desempenharem no dito teatro da História. Entregaram-Ihes uma missão. Ou seja, para uma certa "noção marxista de classe", que Thompson critica, os trabalhadores têm de invariavelmente se comportar "de modo condizente com sua condição proletária". Em outras palavras, Thompson polemiza igualmente com o Marx de a Sagrada família, onde está escrito: "não se trata do que esse ou aquele proletário, ou mesmo o proletariado, imagina em determinado momento como o objetivo. Trata-se do que o proletariado é e do que, de acordo com seu ser, ele será historicamente obrigado a fazer". 9

Então, o interessante a fazer é estabelecer uma distância crítica perante a transformação de um fenômeno histórico e cultural - a classe trabalhadora inglesa do século XIX - na matéria-prima do modelo ideal, um paradigma, diante de que a história de outros grupos de trabalhadores vai provavelmente cair em situação de desvio, falha ou débito. Para tanto, um sugestivo artigo vem ao encontro do debate aqui travado. ${ }^{10}$ Neste, somos advertidos de que 0 fenômeno da classe operária no século XIX europeu, embora certamente democrático, não

\footnotetext{
8 THOMPSON. A formação. Vol. II, pp. 13, 23-27, 28.
}

9 HOBSBAWM. "Introdução ao Manifesto", op.cit., p. 306. HOBSBAWM, Eric. "Trajetória do movimento operário". Revista Trabalhadores, no 2, 1989, p. 5. THOMPSON, E. P. "Algumas observações sobre classe e 'falsa consciência'". As peculiaridades dos ingleses e outros artigos. Campinas: Editora da Unicamp, 2001, p. 271. MARX, Karl. A sagrada família. Citado em CASTORIADIS, Cornelius. A experiência do movimento operário. São Paulo: Brasiliense, 1986: p. 14 (grifos no original).

10 VAN DER LINDEN, Marcel. "Globalizando a historiografia das classes trabalhadoras e dos movimentos operários". Trajetos. Revista de História UFC, № 2, 2002. 
incluía diversos grupos de trabalhadores precários, de rua, ou mesmo braçais, muitas vezes vistos como marginais. Outras clivagens - nada inclusivas - podem ser detectadas: rivalidades étnicas ou o apagamento da presença das mulheres. Não por acaso, classe operária (ou trabalhadora), no seu sentido marxista tradicional, pode bem ser um coeso (e fechado) agrupamento de trabalhadores regularmente assalariados, industriais, masculinos, brancos, e sindicalizados - de preferência em greve. (Curiosamente, o exército invencível do proletariado é composto com os trabalhadores mais disciplinados, isto é, é integrado pelos trabalhadores submetidos pelo capitalismo industrial.) Além dessas restrições, o conceito tem por base (como foi dito) um fenômeno historicamente específico, que não pode ser nem encontrado nem aplicado na história de diversos outros grupos operários. Em acréscimo, ao contrário do que a tradição marxista faz, o fenômeno não se estende no tempo indiferente a tudo que o negue, no tempo ou no espaço.

"As mutáveis relações de produção e as condições de trabalho mutável da Revolução Industrial", escreveu E. P. Thompson (diante de Engels), "não foram impostas sobre um material bruto, mas sobre ingleses livres". Esses trabalhadores, em sua liberdade, cultivaram a "continuidade de tradições políticas e culturais" ancestrais. Logo, os operários tal como os conhecemos, "Ionge de serem os 'filhos primogênitos da Revolução Industrial'" (Thompson cita $A$ situação da classe trabalhadora na Inglaterra) "tiveram nascimento tardio". ${ }^{11}$ Nesse sentido, seguindo um princípio caro ao marxismo - o internacionalismo -, vamos adotar uma perspectiva transatlântica e rodar a baiana: a classe dos escravos legou à formação da classe operária brasileira tradições, valores, identidades e costumes bem como uma rica história de corajosas ou silenciosas iniciativas, grandes ou pequenas, públicas ou privadas. Homens e mulheres africanos ou nativos - foram arrancados de suas famílias e moradas para se tornar trabalhadores nas ruas, manufaturas e sobrados das cidades, ou trabalhadores nas mais variadas fazendas, minas e engenhos de economias coloniais exportadoras. Mesmo assim, apesar das conexões entre as Américas, África e Europa, o fenômeno da formação de uma classe trabalhadora na Inglaterra e em outros países europeus foi muitas vezes estudado sem essas conexões (salvo as do Atlântico Norte)..$^{12}$ É propósito desse artigo salientar que, sem ignorar a existência dessas conexões, a classe operária no Brasil não é exclusivamente derivada da industrialização de feitio europeu. A classe trabalhadora, também por aqui, tem sua aparição no cenário em momento posterior.

\footnotetext{
11 THOMPSON. A formação. Vol. II, pp. 18 e 16.

12 Uma exceção foi: LINEBAUGH, Peter. "Todas as montanhas atlânticas estremeceram". Revista Brasileira de História, oㅡ 6, 1983.
} 
Deste modo, cabe então indicar outro ponto de dissidência de Thompson. No presente caso, ao contrário do que afirmou Marx, a anatomia do homem não explica a anatomia do macaco. Em outras palavras, a classe trabalhadora no sentido marxista tradicional não é 0 sumidouro para o qual é aspirada a história dos trabalhadores que a antecederam. Não se trata, portanto, de procurar traços do "homem" no "ancestral primeiro", mas de entender a História dos trabalhadores que não são um material bruto a que a industrialização capitalista recorre como um pedestal puramente passivo. Para tal, é preciso interrogar um princípio básico do marxismo.

\section{IV}

Nos Princípios básicos do comunismo, Engels se vale da forma do catecismo (perguntas e respostas) para apresentar suas ideias e propostas fundamentais. Dado que desde logo ele evidencia a novidade histórica do proletariado, dizendo ser esta "a classe trabalhadora do século XIX", na questão 6, indaga: "que classes de trabalhadores houve antes da Revolução Industrial?". Na Antiguidade, responde, os trabalhadores eram escravos, "como ainda o são em muitos países atrasados e, inclusivamente, na parte sul dos Estados Unidos". Em seguida, mais uma importante inquirição: "como se diferencia o proletário do escravo?". "O escravo", explica, "está vendido de uma vez para sempre; o proletário tem de se vender a si próprio diariamente e hora a hora". O escravo tem a existência assegurada pelo interesse do seu senhor, enquanto 0 proletário não recebe amparo algum do capitalista. 0 escravo está fora da concorrência; 0 proletário "está dentro dela e sente todas as suas flutuações". "O escravo vale como uma coisa, não como um membro da sociedade civil". Em contraste, "o proletário é reconhecido como pessoa, como membro da sociedade civil". "O escravo pode", conclui Engels, "levar uma existência melhor do que a do proletário, mas o proletário pertence a uma etapa superior do desenvolvimento da sociedade e está ele próprio numa etapa superior à do escravo". Por fim, "0 escravo se liberta para se tornar proletário", o proletário só pode se libertar se abolir a "propriedade privada em geral". ${ }^{13}$

Na capital inglesa, em 1869, também Marx argumentou que não era possível esquecer 0 fundamental: "na antiga Roma, a luta de classes apenas se processava entre uma minoria privilegiada, entre os ricos livres e os pobres livres". Enquanto isso, "a grande massa produtiva da população, os escravos, formava um pedestal puramente passivo para aqueles lutadores". Noutra ocasião, Marx mantém igual proximidade para com Engels. Em Salário, preço e lucro lemos que "nenhuma compra e venda" é celebrada entre senhor e escravo. Não há, "trato algum"

${ }^{13}$ ENGELS, Friedrich. Princípios básicos do comunismo. In: Marx Engels. Obras Escolhidas, Tomo I. Lisboa: Edições Avante!, 1982, pp. 76 e ss. 
a ser feito entre ambos. Como decorrência, o trabalho escravo "parece dado de graça". Mais adiante é comparado o seguinte: se o trabalhador está sujeito à flutuação da economia (muitas vezes tendo de agir e protestar), "o escravo obtém uma quantidade constante e fixa de meios de subsistência". Tem "segurança". ${ }^{14}$

\section{V}

Induzido por pré-noções e ratificado ao ser regurgitado, o grande desconhecimento da relação senhor-escravo - demonstrado acima - comporta elementos familiares aos estudiosos da História Social no Brasil. Vamos a eles; porém brevemente.

O sistema da escravatura é visto como algo marginal, que sobrevive em longínquos países atrasados (aí incluído o Brasil, sobretudo Pernambuco e Bahia, havendo esperanças para São Paulo); ou em regiões atrasadas de países respeitáveis (o Sul dos Estados Unidos). Enquanto isso, os trabalhadores são uma novidade de sociedades avançadas, que se revolucionaram. Numa perspectiva transatlântica, em que o fenômeno do capitalismo surge, se desenrola e se difunde de maneira desigual e combinada, vale a pena perceber a definição de Genovese sobre o Sul estadunidense: "uma sociedade escravista moderna embutida num antitético mercado mundial capitalista". 15

Vendido de uma vez por todas, o escravo vive num mundo de entorpecimento perene, sem história. (O que vale dizer que o escravo também não tem história, a não ser a história da dominação do senhor.) Senhor e escravo não celebram acordo porque a relação está resolvida para sempre; não têm tratos para fazer. De fato, quando a luta operária no decurso do processo produtivo assombrou o mundo em 1968, o argumento de Castoriadis sobre ela fez todo 0 sentido. "Quando o capitalista compra uma tonelada de carvão, sabe quantas calorias pode extrair dela; o negócio para ele já está terminado". Em contraste, "quando ele compra uma jornada de trabalho, o problema apenas começou". O que ele vai poder extrair "como rendimento efetivo será o resultado de uma luta que não cessará um segundo durante a jornada de trabalho". ${ }^{16}$ Ao contrário do que Engels, Marx e as classes dominantes muitas vezes escreveram, inúmeras pesquisas de História Social revelam as dificuldades e revezes dos

\footnotetext{
14 MARX, Karl. 018 de brumário de Luís Bonaparte. In: Marx Engels. Obras Escolhidas, Tomo I. Lisboa: Edições Avante!, 1982, p. 415. MARX, Karl. Salário, preço e lucro. In: Os pensadores. São Paulo: Abril Cultural, 1978, pp. 84 e 94 .

15 GENOVESE, Eugene. The world the slaveholders made. Hanover: Wesleyan University Press, 1988, p. VI. APUD: CANO, Jefferson. "O mundo que os historiadores criaram: Edward Thompson, Eugene Genovese e o tema do paternalismo". Cadernos de história social, № 1, 1995, p. 76.
}

${ }^{16}$ CASTORIADIS. "Introdução: a questão", p. 61. 
senhores em exercerem seu poderio sobre escravos nos eixos, isto é, era muito difícil dominar os escravos como apregoavam e preferiam. Suas queixas, seus desejos satisfeitos de outras maneiras, seus temores, seus pânicos e ojeriza, seus alertas - e tudo isso pode aparecer em seus projetos e estratégias (e nas fontes que produziram) - revelam um quadro de longe muito mais complexo e perturbador, pois havia conflito, tensão, e barganha. Estavam na posição privilegiada, mas não conseguiam fazer com que o subalterno fosse, sempre, uma presa de seu agrado. Ambos disputavam, e brigavam, pela fixação dos limites e dos interstícios dessa relação.

O escravo é vendido; o trabalhador se vende. Mas já não passou da hora de ter com 0 trabalhador escravo o mesmo esforço de compreensão devotado ao trabalhador livre? Pois sabemos que, muitas vezes, o trabalhador simplesmente estava à venda, ou em liquidação, por um trocado ínfimo qualquer. $E$ sabemos também que, mesmo levando Castoriadis em consideração, a política de domínio do capital sobre a mão-de-obra é altamente eficaz. Ainda que tenha de comprar a força de trabalho toda hora, o capitalista atinge suas metas. Não só a linha de montagem, que marca o início do século XX, como a automação, que marca o fim do mesmo século, são de uma precisão constante e minuciosa. Ao contrário do que muitos pensam, crises econômicas, ao mesmo tempo que demonstram fissuras no capitalismo, deprimem e rebaixam os trabalhadores a uma condição subalterna, o que os faz querer acordos desfavoráveis em termos salariais e de condições de trabalho. Em acréscimo, apenas para citar o trabalho de ganho executado por negros escravos, também já sabemos que escravos tinham seus meios para ganhar dinheiro tanto para si quanto para seus senhores. Segundo Maria Cecília Velasco e Cruz, eles:

\begin{abstract}
"possuíam autonomia e liberdade de movimento sem as quais não poderiam encontrar, negociar e executar os trabalhos que aparecessem. Muitos não moravam na casa dos seus senhores, e só iam lá para entregar a quantia estipulada por dia ou por semana. Tudo que recebiam além deste acerto podiam embolsar, o que thes dava melhores condições para juntar um pecúlio e comprar a liberdade. Eram, contudo, trabalhadores assalariados na relação que mantinham com quem os contratava para executar uma tarefa, mas como escravos viviam sob o arbítrio do senhor, que poderia vendê-los quando bem entendesse". 17
\end{abstract}

Com suas rotas transnacionais, além de terem feito do oceano Atlântico um rio navegável, os escravos também trafegavam com incrível mobilidade, rapidez, eficiência, e sistemática entre o campo e a cidade, seduzindo negros cativos para a causa da liberdade. Era 0

17 VELASCO E CRUZ, Maria Cecília. "Tradições negras na formação de um sindicato de resistência dos trabalhadores em trapiche e café. Rio de Janeiro (1905-1930)”. Afro-Ásia, no 24, 2000, p. 255. 
que atestavam seus senhores, a polícia, e outras autoridades. Mais ainda, também paralisavam suas atividades e faziam reivindicações, às vezes exigências. ${ }^{18}$ Além disto, como é largamente sabido, certos escravos trabalhavam vendendo sua força de trabalho, recebiam dinheiro por isto e, guardando esse numerário, até obtinham a sua liberdade, comprando-a.

O escravo está seguro por causa do interesse do senhor em mantê-lo vivo. 0 trabalhador vive a instabilidade e a precariedade do mercado. Para não falar das famílias (que existiam dentro das senzalas) desfeitas pelo ato senhorial da venda de escravos (levando insegurança à organização familiar), prestemos também atenção em Michelle Perrot que, na França, destaca a importância do paternalismo industrial. Logo, nem só o senhor de escravos era paternalista, pelo que devia providenciar o sustento de seu serviçal de maneira nãoassalariada (a dita segurança). Ora concorrente, ora dissentindo de políticas estatais, a política assistencial da iniciativa privada tem sido aplicada, em época mais recente, como exemplo tanto da sensibilidade social da empresa privada quanto de abundância capitalista. Havia interesse da parte dos patrões em fixarem ou estabilizar uma mão-de-obra assalariada vista como flutuante. Também havia interesse em assegurar a lealdade dos trabalhadores à iniciativa privada, diante do comunismo, com políticas corporativas de bem-estar capitalista. ${ }^{19}$

"Seja onde ou quando for, toda vez que populações rurais vivem pela primeira vez a ignorada experiência da disciplina do sistema de produção moderna e as oportunidades inéditas do mundo urbano", calculou-se, "há geralmente uma alta taxa de rotatividade entre os trabalhadores desqualificados". Por isso, no Brasil, as firmas estadunidenses pagavam salários superiores ao mínimo fixado pelo governo. As diferenças culturais do trabalhador sertanejo parte delas referentes a "atitudes diante do trabalho e da fábrica moderna", aos "valores vinculados a compensações monetárias e não-monetárias e ao consumo material" — podiam ser grandes a ponto de inquietar e atrapalhar. Daí a importância de segurar a mão-de-obra local. ${ }^{20}$ Em síntese, ao contrário do que reza o catecismo, nem sempre o escravo viveu na "segurança" da providência de seu senhor nem tampouco o trabalhador assalariado viveu na insegurança do

\footnotetext{
${ }^{18}$ SOARES, Carlos E. L.; GOMES, Flávio dos S. "Sedições, haitianismo e conexões no Brasil escravista". Novos estudos, no 63, 2002. GOMES, Flávio dos S. Histórias de quilombolas. Mocambos e comunidades de senzalas no Rio de Janeiro, século XIX. Rio de Janeiro: Arquivo Nacional, 1995. REIS, João. "A greve negra de 1857 na Bahia". Revista USP, № 18, 2003.

${ }^{19}$ PERROT, Michelle. "As três etapas da disciplina industrial na França do século XIX". Os excluídos da História. Rio de Janeiro: Paz e Terra, 1988. NEGRO, Antonio Luigi. "Automóveis 100\% nacionais para Argentina e Brasil. Parceria desenvolvimentista no além-mar". In: FORTES, Alexandre et alli. Na luta por direitos. Estudos recentes em história social do trabalho. Campinas: Editora da Unicamp, 1999.

20 GEIGER, Theodore. US business performance abroad. The case study of General Electric company in Brazil. Washington: National Planning Association, 1961, p. 83.
} 
mercado livre, pois havia interesse em segurá-lo em seu emprego seja por esse ou aquele motivo.

Clássico na boca dos clássicos, o escravo é coisa. E o trabalhador é pessoa e membro da sociedade civil. O escravo pode levar uma vida segura e mesmo melhor, mas vive numa etapa inferior. O trabalhador é explorado, mas é personagem de uma etapa superior do desenvolvimento. O "elemento servil", em Roma, oferecia à plebe um pedestal puramente passivo, no qual os pobres livres se assentavam para lutar. Eruditos e exímios conhecedores da França, Engels e Marx podiam ter lido com outros olhos expressiva fonte coletada por Hobsbawm (que remete, não para desníveis, mas para conexões entre trabalhadores escravos e livres):

"todo fabricante vive em sua fábrica como os plantadores coloniais no meio de seus escravos, um contra uma centena, e a subversão de Lyon é uma espécie de insurreição de São Domingos. (...) Os bárbaros que ameaçam a sociedade não estão nem no Cáucaso nem nas estepes tártaras; estão nos subúrbios de nossas sociedades industriais". ${ }^{21}$

\section{VI}

Sendo a (supracitada) rebeldia operária em Lyon quem antecede, no continente europeu, a insinuação do cartismo como primeiro movimento operário nacional do mundo, sinal de sua formação madura, considerando a rebeldia de Lyon é uma "espécie de insurreição de São Domingos", é hora então de falar o seguinte: ao mesmo tempo em que os cercamentos produziram a figura do trabalhador dito livre, outros cercamentos - outras usurpações - criaram a figura do trabalhador dito escravo. Assim como se aprisionaram terras comunais atrás de cercas, se fecharam pessoas em navios e ferros. Se o primeiro veio a constituir uma classe historicamente relevante, o segundo fez o mesmo, e ambos, seguramente, compartilharam espaços, valores, iniciativas e práticas em muito maior medida do que Engels e Marx, em seus princípios básicos, pensaram ou admitiram.

Conforme Tom Bottomore, quando Marx dirige sua atenção para o processo pelo qual o capitalismo se afirmou historicamente, ele oferece uma resposta simples ao abordar a Inglaterra. ${ }^{22}$ "Uma vez que as relações de produção pré-capitalistas são predominantemente agrícolas, dispondo os camponeses dos principais meios de produção, como a terra, 0

21 Journal des Débats, 8/12/1831. APUD: HOBSBAWM, Eric. A era das revoluções. Rio de Janeiro: Paz e Terra, 1977 , p. 221.

22 BOTTOMORE, Tom. "Acumulação primitiva de capital". BOTTOMORE, Tom (org.). Dicionário do pensamento marxista. Rio de Janeiro: Jorge Zahar Editor, 1988, p. 2. 
capitalismo só se pode afirmar esbulhando os camponeses de sua terra". Assim sendo, as origens do capitalismo se situam "na transformação das relações de produção no campo", sendo o apartheid entre os camponeses e a terra "o manancial de onde provêm os trabalhadores assalariados". A isso deve-se acrescentar a perspectiva transatlântica:

"há eventos profundos e hemisféricos que se originam abaixo da superfície das coisas e que não estão confinados a qualquer nação em particular, surgindo sim de todos os quatro cantos do Atlântico". 23

Indígenas, africanos, ou mestiços, os escravos não formaram uma classe operária (um proletariado) no sentido marxista tradicional, mas formavam (como se referiu Thompson à plebe inglesa dos setecentos) uma classe social sui generis: subalterna, dominada, trabalhadora - e, óbvio, dona de sua própria história. Se Engels e Marx elegeram o proletariado industrial, é preciso ter em mente que, de novo conforme E. P. Thompson, a ofensa primeira do capitalismo foi etiquetar com um cifrão o conjunto do mundo da vida e do trabalho, a começar pela terra e por vidas humanas, dissolvendo-o em operações de compra e venda, reduzindo-o a termos econômicos.

Deste modo, no lugar da placidez ou da nulidade das relações sociais de produção nas colônias, encontramos outras questões:

\begin{abstract}
"quem tem enchido e enche de cadáveres os sepulcros? Quem constróis na oficina da fome denegridos e áridos esqueletos que apenas nos suspiros com que explicam sua precisão dão sinal de viventes? Quem despovoa lugares inteiros para povoar desertos? Quem faz delinqüentes tantos inocentes sem delito? Quem deixa órfãos muitos filhos que ainda têm pais vivos? Quem há de ser senão a mita? Ela mata tudo o que vê, desola o que encontra, cativa quanto pode. A mita é um açoite com que a ira divina castiga estes povos". ${ }^{24}$
\end{abstract}

Nesse sentido, antes do surgimento do proletariado industrial assalariado, os escravos foram ativos e centrais na formulação de tradições, práticas, crenças, identidades, valores, formas de organização - com sua cultura e linguagem de classe - que informam os mundos do trabalho livre cujo aparecimento é recente, no século XX. Foram, portanto, fundamentais na definição desse "agregado de microcosmos", dessa "coleção de pequenos mundos, com

\footnotetext{
${ }^{23}$ LINEBAUGH. "Todas as montanhas", cit., p. 7.

24 DE MERISALDE Y SANTISTEBAN, Joaquín. Relación histórica, política y moral de la ciudad de Cuenca. Madrid: Librería de Victoriano Suárez, 1894 [1a edição de 1765], p. 90. Agradeço a Evergton Sales Souza a indicação desta fonte.
} 
freqüência estritamente autônomos" que depois formaram uma classe trabalhadora correspondente ao sentido marxista tradicional. ${ }^{25}$

No pioneirismo da industrialização têxtil brasileira, a Bahia não se restringiu a Salvador. Sita no Recôncavo, a Industrial Cidade de Valença foi ponto de parada de um giro pelo Brasil, feito por dois viajantes estadunidenses. Estes avistaram nas margens de um rio "muitas negras e mulatas ocupadas lavando roupa". Olhando-as, um deles pensou, pela primeira vez na vida, no "incômodo do vestuário em matéria de trabalho manual". Essas baianas "cujos retintos membros arredondados eram macios" estavam "nuas até a cintura". As crianças, por sua vez, estavam no estado "puris naturabilis". Em seguida, se depararam com a "imensa" fábrica, ou melhor, com as fábricas: o parque da Fábrica Todos os Santos (provavelmente). "A matraca dos teares, 0 animador sorriso de moças alegres, 0 indescritível barulho e zunido da fábrica me fizeram quase me ver nas cercanias de Lowell". Talvez estimulado pela arredondada e macia nudez das negras, é possível que a unidade fabril visitada não fosse assim tão parecida com Lowell (Massachusetts, um dos estados mais industrializados dos EUA), mas é certo que a viagem, os cenários, as pessoas e as dependências fabris eram impressionantes. Os operosos homens e mulheres que lá trabalhavam provinham do asilo de órfãos ou do hospital dos enjeitados. Elevados moral e disciplina havia, com feitor negro.

Em Salvador, os bons homens testemunharam mais uma "peculiaridade da Bahia". Dadas a irregularidade da superfície e a disparidade de nível existente entre as cidades alta e baixa, não se admitia o uso de veículos sobre rodas. "O que quer que requeira mudança de lugar em todo comércio e negócio ordinário do porto" haveria de passar pela cabeça ou ombros dos homens. Por causa disso,

\footnotetext{
"um sem-número de negros altos e atléticos é visto em movimento em duplas ou turmas de quatro, de seis, ou oito, com suas cargas suspensas entre eles em traves. Outros tantos de seus camaradas são encontrados sentados sobre os paus, cestos de palha, ou languidamente repousando nas vielas e esquinas das ruas, lembrando cobras pretas enrodilhadas à luz do sol. Os que dormem geralmente têm uma sentinela pronta para chamá-los assim que se os requisitam para o serviço, e ao sinal eles se levantam (...). Como os carregadores de café do Rio, costumam gritar e cantar enquanto andam, mas seu molejo é necessariamente lento e medido, assemelhando-se mais a uma marcha fúnebre do que ao ágil passo duplo de seus parceiros fluminenses". 26
}

\footnotetext{
25 HOBSBAWM, Eric. "O fazer-se da classe operária, 1870-1914". Mundos do trabalho. Rio de Janeiro: Paz e Terra, 1987, pp. 278 e 279

${ }^{26}$ FLETCHER, James C.; KIDDER, Daniel. Brazil and the Brazilians: portrayed in historical and descriptive sketches. Boston: Little, Brown, 1867, p. 475, 476, 478. Maria C. V. e Cruz, com mais profundidade, analisou fontes semelhantes em Tradições negras, op. cit., pp. 257-260. Sobre o "enigma baiano" (o que sucedeu ao pioneirismo industrialista têxtil da Bahia), ver: STEIN, Stanley. The Brazilian Cotton Manufacture. Textile Enterprise in an
} 
Enfim, a cana, a farinha, o fumo, o café ou o algodão, etc., nas mais diversas regiões, integravam uma economia que, em algum momento, passou também a funcionar com usinas de açúcar, pequenas fábricas de juta, de óleo, além de usinas de beneficiamento de arroz, ou manufaturas de bens de consumo não-duráveis, ligando-se aos serviços (públicos e domésticos, também íntimos) prestados e a tropas e feiras, ao porto, à ferrovia. Da mesma maneira que rural e urbano estão vinculados, a história do trabalhador escravo não é uma experiência que não guarda relação alguma com o trabalho livre (inclusive assalariado) - em termos étnicos, de gênero, no seu próprio tempo e lugar. Não são pólos antagônicos e excludentes. Tampouco são hierarquizáveis, em degraus de superioridade, pré-político, marginalidade ou atraso.

\section{VII}

"Constantemente", adverte Engels, "utilizei como sinônimos as expressões trabalhadores (working men), proletários, classe operária, classe não-proprietária e proletariado". Querendo ser simples, esse artigo não se apega aos (não muito bem-sucedidos) esforços de detalhada teorização do conceito de classe, lacuna que Marx e Engels deixaram. Em alguns intentos surgiram áridas formulações. Noutros, o fosso entre o conceito e o fenômeno foi alargado, 0 ideal se descolando da realidade. Acertar as contas, teoricamente, com Marx e Engels levou ao esquecimento da história, à desconsideração de sujeitos históricos extraordinários. Paralelamente, o afã de prosseguir com uma exclusiva e "verdadeira ciência" para o "socialismo internacional moderno" (o que Marx teria feito, segundo Engels) tem levado o marxismo enquanto doutrina - a prescrever uma consciência verdadeira à história do proletariado.

Sim, o escravo se tornou proletário, mas não no sentido marxista usual. Antes dos operários, "a Bahia ficou célebre não só por sapateiros ou alfaiates bravamente políticos", escreveu Freyre, mas também pelos próprios escravos - igualmente - "políticos e bravos no sentido de terem se organizado em revoltas que foram no Brasil verdadeiras revoluções a favor dos direitos sociais". 27 Tal questão, contudo, é por demais delicada e difícil e pouco adianta erguê-la em achado histórico se não levarmos em consideração, como adverte João Reis, que "a ideologia racial predominante na Bahia" preferia "enormemente os mestiços sobre os negros" e que "tensões raciais" deviam existir entre trabalhadores mestiços e negros. Apenas o desenvolvimento da pesquisa poderá confirmar ou infirmar, continua Reis, a profundidade do

Underdeveloped Area, 1850-1950. Cambridge: Harvard University Press, 1957. TAVARES, Luís H. D. O problema da involução industrial da Bahia. Salvador: UFBa, 1966. HEROLD, Marc W. "Entre o açúcar e o petróleo: Bahia e Salvador, 1920-1960". Revista espaço acadêmico, № 42, 2004.

27 ENGELS. A situação, op. cit., pp. 9 e 368. FREYRE, Gilberto. Bahia e baianos. Salvador: Fundação das Artes/EGBA, 1990, p. 69. 
"reconhecimento de que eram todos - ou quase todos - negros ou tratados como tais, numa sociedade dominada pelos brancos". 28 "Toda experiência histórica é obviamente, em certo sentido, única", disse Thompson. Para ele, assim como para Engels, a concepção materialista da História não podia servir como uma desculpa "para não estudar a História". ${ }^{29}$ É o que nos resta continuar fazendo.

${ }^{28}$ REIS, João. "De olho no canto: trabalho de rua na Bahia na véspera da abolição". Afro-Ásia, no 24, 2000, p. 241.

${ }^{29}$ THOMPSON. "As Peculiaridades...", cit., pp. 79 e 133. 